\title{
Activation of inflammatory cells by immune complexes containing IgE in serum and synovial fluid of patients with rheumatoid arthritis: a study using flow cytometric analysis
}

\author{
L S De Clerck, N J Struyf, C H Bridts, W J Stevens
}

\begin{abstract}
Neutrophil and monocyte activation by immune complexes containing IgE from serum and synovial fluid of patients with rheumatoid arthritis is reported. Activation of the inflammatory cells was measured by stimulation of the respiratory burst with production of intracellular hydrogen peroxide. Generation of hydrogen peroxide was analysed by a flow cytometric method, using the fluorochrome dichlorofluorescein. The technique was modified to allow measurement of cell activation of both neutrophils and monocytes by immune complexes in suspension. Ten of 14 polyethylene glycol precipitates from serum of patients with rheumatoid arthritis and 10/16 synovial fluids of these patients could activate neutrophils. A positive relation was found between the activation of neutrophils and the total concentration of immune complexes, the presence of IgG, and the presence of IgE in the immune complexes. Activation of monocytes was also shown, but to a lesser extent $(8 / 14$ rheumatoid serum samples and 8/16 rheumatoid synovial fluids activated monocytes). There was a weak correlation between the concentration of IgE immune complexes and the intensity of fluorescence measured in the monocytes.
\end{abstract}

In an earlier study we demonstrated in vitro neutrophil activation by immune complexes containing IgE. To measure superoxide release in the supernatant immune complexes had to be coupled onto plastic wells. Moreover, activation of monocytes could not be shown.

Here the activation of both neutrophils and monocytes by immune complexes in suspension was studied by flow cytometric analysis. The technique used was based on the method of Bass et $a{ }^{2}{ }^{2}$ measuring the intracellular hydrogen peroxide production through oxidation of added 2',7'-dichlorofluorescin diacetate. The technique was modified to allow measurement of cell activation of both neutrophils and monocytes by immune complexes in suspension.

We used this technique to explore the role of immune complexes containing IgE in serum and synovial fluid of patients with rheumatoid arthritis in the activation of these inflammatory cells.

\section{Patients and methods}

PATIENTS AND CONTROLS

Polyethylene glycol (PEG) precipitates of 14 serum samples and of 16 synovial fluids of patients with classical or definite rheumatoid arthritis were studied. Twenty of these 30 samples were positive for immune complexes containing IgE, 10 were negative. A total immune complex score was calculated; thus immune complexes containing IgG, IgA, and IgM were also determined. The total immune complex score was defined as the sum of the four different isotypes (IgG, IgA, IgM, and IgE) of immune complexes divided by their respective cut off values. Twelve samples had a high immune complex score $(>8), 18$ were $<8$. Only three samples were negative for immune complexes containing IgG, IgM, IgA, and IgE. Ten PEG precipitates from normal subjects, all negative for $\mathrm{IgE}$ and other isotypes of immune complexes, served as controls. All samples were kept at $-20^{\circ} \mathrm{C}$ until used.

\section{IMMUNE COMPLEX PRECIPITATION AND} DETERMINATION

Immune complexes were precipitated from patient serum samples and synovial fluids with PEG 6000, (Merck, Darmstadt, FRG). ${ }^{3}$ IgE, IgA, and IgM immune complex determinations were made by an enzyme linked immunosorbent assay (ELISA). ${ }^{4}$ Briefly, microtitre plates (Costar, Cambridge, USA) were coated with rabbit antihuman IgE (Dako, Glostrup, Denmark), goat antihuman IgA (Tago, Burlingame, USA), or rabbit antihuman IgM. Polyethylene glycol precipitates diluted 1/1 (IgE) or $1 / 500$ (IgA and $\operatorname{IgM}$ ) were added to the wells and incubated overnight at $4^{\circ} \mathrm{C}$. IgE was detected with biotinylated mouse monoclonal antihuman IgE (Diagnostics Pasteur, Marnes, France) and peroxidase labelled streptavidin (Amersham, Amersham, UK). IgA and IgM were detected with peroxidase conjugated $\mathrm{F}\left(\mathrm{ab}^{\prime}\right)_{2}$ goat antihuman IgA and IgM (Tago) respectively. Immune complexes containing IgE were calibrated with an IgE reference preparation (Behringwerke AG), IgA and IgM immune complex assays with $\mathrm{N}$ protein standard serum (Behringwerke AG, Marburg, FRG). Immune complexes containing IgG were determined by a radioimmunoassay using iodinated protein A (Amersham).

The 95th centile of the serum values of 75 normal subjects matched for age was taken as cut off value.

\section{CELL FRACTIONATION}

Heparinised blood was obtained from a normal donor. After centrifugation a buffy coat was collected and washed in Hanks's balanced salt 
solution without $\mathrm{Mg}^{2+}, \mathrm{Ca}^{2+}$, and phenol red (pH 7.4; Gibco, Paisley, UK). Cells were then fractionated on a discontinuous Percoll density gradient (Percoll, Pharmacia LKB, Uppsala, Sweden). Mononuclear and polymorphonuclear cells were washed twice in Hanks's balanced salt solution without $\mathrm{Mg}^{2+}, \mathrm{Ca}^{2+}$, and phenol red, and concentrated to $10^{7} \mathrm{cells} / \mathrm{ml}$ in phosphate buffered saline with $0.1 \%$ gelatin and $0.1 \%$ glucose (pH 7·4).

\section{CELL ACTIVATION}

For the cell activation PEG precipitates were washed in $2.5 \%$ polyethylene glycol and concentrated twice in phosphate buffered saline with $0.1 \%$ gelatin and $0.1 \%$ glucose $(\mathrm{pH} 7 \cdot 4)$. The activation obtained with the PEG precipitates was compared with the activation caused by heat aggregated human $\operatorname{IgG}^{3}$ or formylmethionyl-leucyl-phenylalanine (fMLP, final concentration $10^{-6} \mathrm{~mol} / \mathrm{l}$; Sigma, St Louis, USA).

Cells were incubated with $2^{\prime}, 7^{\prime}$-dichlorofluorescin diacetate, a non-fluorescent compound that easily diffuses into the cells. This diacetate hydrolysed to $2^{\prime}, 7^{\prime}$-dichlorofluorescin and afterwards oxidised to the highly fluorescent $2^{\prime}, 7^{\prime}$-dichlorofluorescein by intracellular hydrogen peroxide. $2^{\prime}, 7^{\prime}$-Dichlorofluorescein is a polar molecule and thus trapped in the cell. It is an indicator of the respiratory burst in stimulated inflammatory cells. Cells $(0.1 \mathrm{ml})$ were incubated with $0.1 \mathrm{ml} \mathrm{2} 2^{\prime}, 7^{\prime}$-dichlorofluorescin diacetate (final concentration 0.01 $\mathrm{mg} / \mathrm{ml}$ in phosphate buffered saline with $0.1 \%$ gelatin and $0.1 \%$ glucose; Eastman Kodak Company, Rochester, USA) for 15 minutes at $37^{\circ} \mathrm{C}$. Thereafter, $0 \cdot 1 \mathrm{ml}$ of a $\mathrm{Ca}^{2+}$ and $\mathrm{Mg}^{2+}$ solution $\left(0 \cdot 1 \mathrm{mg} / \mathrm{ml} \mathrm{CaCl}_{2} \cdot 2 \mathrm{H}_{2} \mathrm{O}\right.$ and $0 \cdot 1 \mathrm{mg} / \mathrm{ml}$ $\mathrm{MgCl}_{2} \cdot 6 \mathrm{H}_{2} \mathrm{O}$ in phosphate buffered saline with $0.1 \%$ gelatin and $0.1 \%$ glucose and $0.1 \mathrm{ml}$ of the stimulus were added and incubation was prolonged for 30 minutes at $37^{\circ} \mathrm{C}$. Reaction was stopped with $1 \mathrm{ml}$ cold phosphate buffered saline with $0 \cdot 1 \%$ gelatin and $0 \cdot 1 \%$ glucose and intracellular $2^{\prime}, 7^{\prime}$-dichlorofluorescein fluorescence was measured by flow cytometry (FACScan; Becton Dickinson, Sunnyvale, USA). Cells were gated by forward scatter and side scatter analysis methods, and results were expressed as the $\ln$ mean fluorescence per cell by conversion of logarithmic channel numbers into relative linear fluorescence intensity. ${ }^{5}$

\section{STATISTICAL ANALYSIS}

Statistical analysis was carried out by nonparametric analysis of variance (Kruskal-Wallis), the Wilcoxon matched pairs signed rank test, the Spearman rank correlation coefficient, and the $\chi^{2}$ test, where appropriate. A p value $<0.05$ was considered significant.

\section{Results}

NORMAL SERUM SAMPLES

Neutrophils The mean In fluorescence (SD) of polymorphonuclear cells caused by the 10 control PEG precipitates was $0.98(0 \cdot 19)$. The mean +2 SD of the 10 control PEG precipitates was taken as the cut off point. All the control values were below this limit.

Monocytes The mean $\ln$ fluorescence (SD) was $1.67(0.09)$. As for the polymorphonuclear cells, all the control values were below the mean +2 SD.

\section{RHEUMATOID ARTHRITIS SAMPLES}

Neutrophils Ten of 14 rheumatoid arthritis PEG precipitates from serum and 10/16 from synovial fluid led to enhanced fluorescence of polymorphonuclear cells (patients $v$ controls: $p=0.001$, table). Of the 20 IgE immune complex positive samples (serum and synovial fluid taken together), 14 activated polymorphonuclear cell oxidative metabolism.

Polyethylene glycol precipitates of patients with rheumatoid arthritis added to polymorphonuclear cells labelled with $2^{\prime}, 7^{\prime}$-dichlorofluorescin diacetate gave on average $65 \%$ of the fluorescence intensity of heat aggregated human IgG, whereas fMLP gave a lower activation ( $34 \%$ of the aggregated IgG value).

Figure 1A shows an example of a strongly stimulatory PEG precipitate of a patient with rheumatoid arthritis in comparison with heat aggregated human IgG and fMLP.

Monocytes Eight of PEG precipitated serum samples and 8/16 synovial fluids of patients with rheumatoid arthritis activated normal donor monocytes, though the activation was less than for polymorphonuclear cells. Ten of $20 \mathrm{IgE}$ immune complex positive rheumatoid arthritis samples caused a significant activation of monocytes, whereas none of the 10 PEG precipitates of normal controls led to enhanced fluorescence of the cells. Immune complexes of patients with rheumatoid arthritis added to $2^{\prime}, 7^{\prime}$-dichlorofluorescin diacetate labelled cells gave on average $82 \%$ of the intensity of heat aggregated IgG stimulated cells. The monocyte activation

Polymorphonuclear cell activation in relation to diagnosis and immune complexes

\begin{tabular}{|c|c|c|c|}
\hline & \multicolumn{2}{|c|}{$\begin{array}{l}\text { Polymorphomuclear cell } \\
\text { activation }\end{array}$} & \multirow[t]{2}{*}{ p Value } \\
\hline & Positive & Negative & \\
\hline $\begin{array}{l}\text { Diagnosis } \\
\text { Controls } \\
\text { RA† serum samples } \\
\text { RA synovial fluids }\end{array}$ & $\begin{array}{r}0 \\
10 \\
10\end{array}$ & $\begin{array}{r}10 \\
4 \\
6\end{array}$ & 0.001 \\
\hline $\begin{array}{l}\text { Total CIC† score: } \\
>8 \\
<8 \\
\text { IgG CIC: } \\
\text { Positive } \\
\text { Negative }\end{array}$ & $\begin{array}{r}11 \\
9 \\
17 \\
3\end{array}$ & $\begin{array}{r}1 \\
19 \\
7 \\
13\end{array}$ & $<0.002$ \\
\hline $\begin{array}{c}\text { IgA CIC: } \\
\text { Positive } \\
\text { Negative }\end{array}$ & $\begin{array}{r}8 \\
12\end{array}$ & $\begin{array}{r}4 \\
16\end{array}$ & NS \\
\hline $\begin{array}{c}\text { IgM CIC: } \\
\text { Positive } \\
\text { Negative }\end{array}$ & $\begin{array}{l}10 \\
10\end{array}$ & $\begin{array}{r}5 \\
15\end{array}$ & NS \\
\hline $\begin{array}{c}\text { IgE CIC: } \\
\text { Positive } \\
\text { Negative }\end{array}$ & $\begin{array}{r}14 \\
6\end{array}$ & $\begin{array}{r}6 \\
14\end{array}$ & $<0.05$ \\
\hline
\end{tabular}



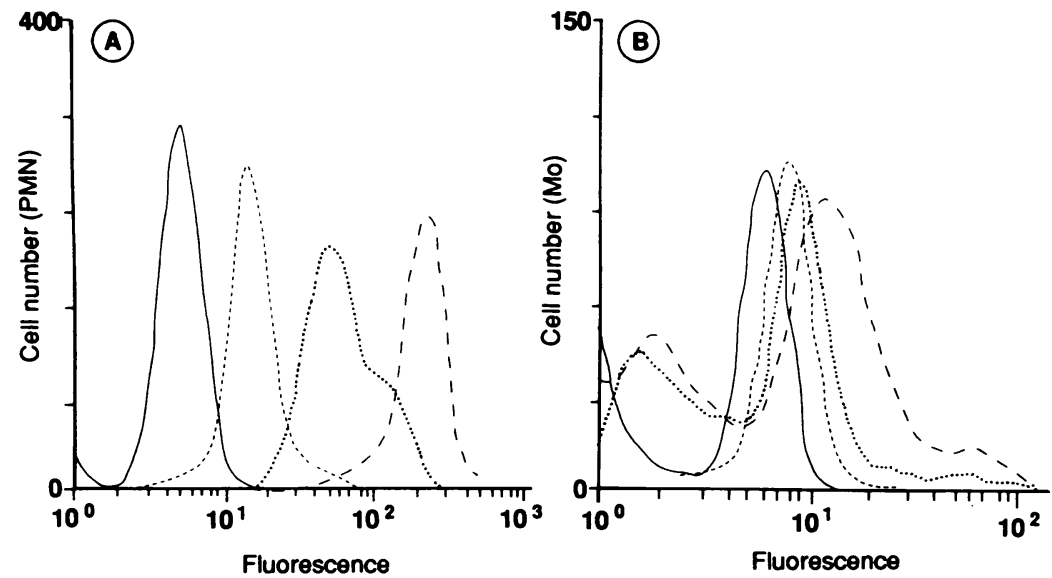

Figure 1 Fluorescence histograms of resting $(-)$ and stimulated $(A)$ polymorphonuclear cells $(P M N)$ and $(B)$ monocytes $(M o)$ after incubation with $2^{\prime}, 7^{\prime}$-dichlorofluorescin diacetate. Cells were stimulated by formyl-methionyl-leucyl-phenylalanine (- - -), heat aggregated human IgG $(\cdots \cdot)$, polyethylene glycol precipitate (- - ).
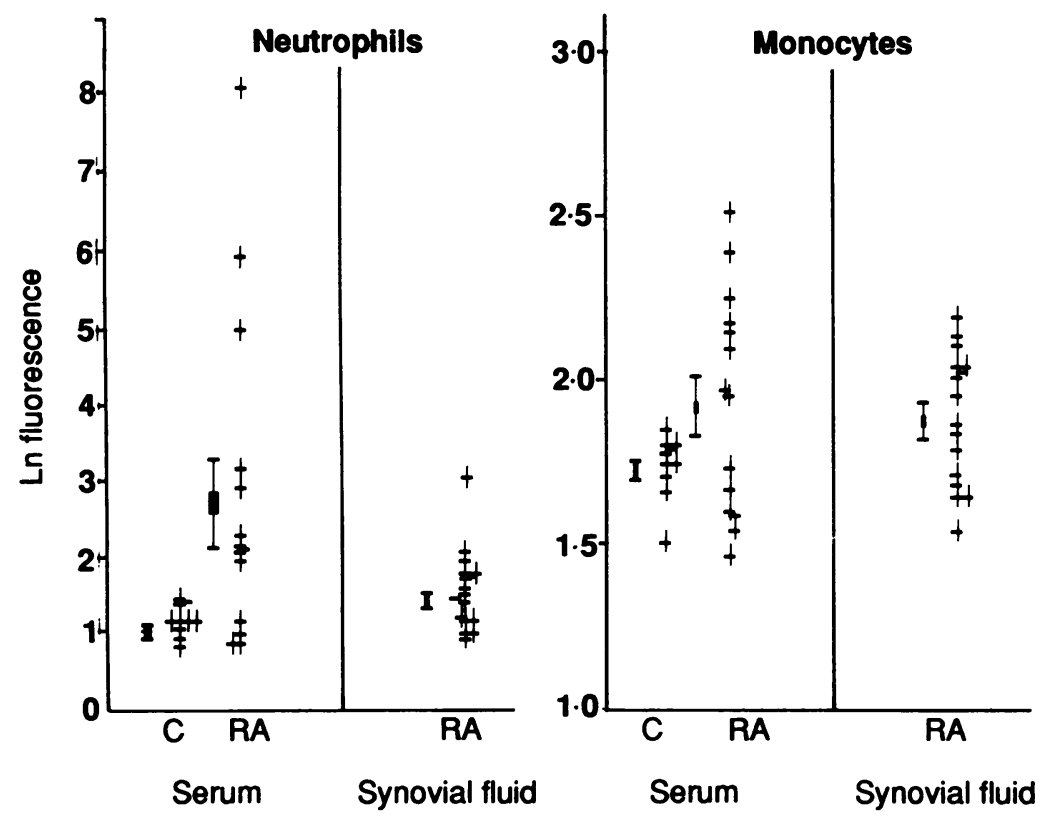

Figure 2 Mean fluorescence (In fluorescence) per cell of normal donor neutrophils and monocytes stimulated by polyethylene glycol precipitates from serum samples of patients with rheumatoid arthritis $(R A)$ and from controls $(C)$ or from $R A$ synovial fluids.

induced by $\mathrm{fMLP}$ was $80 \%$ of the aggregated IgG value. Figure $1 B$ shows an example of a stimulatory PEG precipitate.

COMPARISON OF RHEUMATOID ARTHRITIS SERA WITH SYNOVIAL FLUIDS

Figure 2 shows the results of polymorphonuclear cell and monocyte fluorescence for controls, rheumatoid arthritis serum samples and synovial fluids.

There was no statistically significant difference in stimulatory effect between PEG precipitates from serum and from synovial fluid.

RELATION BETWEEN INFLAMMATORY CELL ACTIVATION AND IMMUNE COMPLEX CONCENTRATIONS

A positive relation was found between the activation of polymorphonuclear cells and the presence of an increased total immune complex score (table). When the different isotypes were considered a positive relation was found between IgG and IgE in the complexes and the activation of polymorphonuclear cells. For monocytes there was a weak but significant $(r=0.32, p=0.03)$ correlation between the concentration of $\mathrm{IgE}$ immune complexes and the intensity of fluorescence measured.

\section{Discussion}

Flow cytometry is a useful technique for studying cells in suspensions; its sensitivity makes it possible to calculate cell per cell fluorescence. It is possible to apply this principle for the measurement of intracellular hydrogen peroxide produced in the respiratory burst: added dichlorofluorescin diacetate can readily be oxidised by intracellular hydrogen peroxide to highly fluorescent dichlorofluorescein. In this way activation of neutrophils can be studied. ${ }^{2} 6$

By this technique we have shown that immune complexes containing IgE from serum samples and synovial fluids of patients with rheumatoid arthritis can stimulate oxidative metabolism of polymorphonuclear cells. This makes the test system used more sensitive than assays formerly described which used the extracellular reduction of cytochrome $c{ }^{7}$ and in which immune complexes had to be coupled onto plastic wells to release a measurable amount of superoxide. ${ }^{1}$ In this study we found a positive relation between the activation of polymorphonuclear cells and complexes in suspension containing IgG and IgE.

It is well known that monocytes produce less hydrogen peroxide in the respiratory burst than neutrophils. ${ }^{8}$ Although less obvious, activation of monocytes could also be shown in this study. The technique used made it possible to study activation of monocytes by immune complexes without prior enriching procedures and thus without the danger of activation of cells by these manipulative procedures.

It has been shown earlier that immune complexes containing IgE are more prevalent in patients with severe arthritis and in patients with vasculitis, ${ }^{4-11}$ and that these complexes can activate polymorphonuclear cells ${ }^{1}$ and basophils. ${ }^{12}$ This study provided further evidence for the inflammatory role of IgE immune complexes in rheumatoid arthritis, showing that mononuclear cells could also be activated by these complexes. This might be expected since it has been shown that some monocytes and macrophages possess IgE-type II receptors with a high affinity for aggregated IgE. ${ }^{13}$ Moreover, we found a weak but significant correlation between the concentration of circulating immune complexes containing IgE and the intensity of intracellular fluorescence measured in the monocytes.

In summary, the results of this study confirm our previous experiments showing the activation of neutrophils by IgE immune complexes fixed to plastic wells, and extend these findings to immune complexes in suspension - that is, serum and synovial fluid. Furthermore, the technique used allowed us to show activation of monocyte 
respiratory burst by immune complexes containing IgE of patients with rheumatoid arthritis, which could not be shown by the former technique.

This work was supported by a grant $(9.0030 .87)$ of the Nationaal Fonds voor Geneeskundig Wetenschappelijk Onderzoek.

I De Clerck L S, Gigase P L, Bridts C H, Stevens W J. Neutrophil activation by IgE-containing circulating immune complexes of patients with connective tissue diseases. complexes of patients with connective

2 Bass D A, Parce J W, DeChatlet L R, Szeda P, Seeds M C Thomas M T. Flow cytometric studies of oxidative product Thomas M T. Flow cytometric studies of oxidative product formation by neutrophils. F Immunol 1983; 130: 1910-7.
Stevens $W$ J, Bridts C. A method for rapid determination of 3 Stevens W J, Bridts C. A method for rapid determination of IgG-containing circulating immune complexes using polyethyleneglycol and radioactively labeled protein A. Immunol Lett 1981; 3: 1-4.

4 De Clerck L S, Struyf N J, Bridts C H, et al. Humoral immunity and composition of immune complexes in patients with rheumatoid arthritis with special reference to IgE-containing immune complexes. Clin Exp Rheumatol 1989; 7: 485-92.

5 Schmid I, Schmid P, Giorgi J V. Conversion of logarithmic channel numbers into relative linear fluorescence intensity. Cytometry 1988; 9: 533-8.

6 Duque R E Ward P A Quantitative assessment of neutrophil function by flow cytometry. Anal Quant Cytol Histol 1987; function by flow cytometry. Anal Quant Cytol Histol 1987 9: 42-8.

Babior B M, Kipnes R S, Curnutte J T. Biological defense mechanisms: the production by leucocytes of superoxide, a potential bactericidal agent. $\mathcal{J}$ Clin Invest 1973; $52: 741-4$

8 Roos D, Balm A J M. The oxidative metabolism of monocytes. In: Sbarra A J, Strauss $R$, eds. The reticuloendothelial system. A comprehensive treatise. 2. Biochemistry and metabolism. New York: Plenum Press, 1980. 189-229.

9 Meretey K, Falus A, Erhardt C C, Maini R N. IgE and IgErheumatoid factors in circulating immune complexes in
rheumatoid arthritis. Ann Rheum Dis 1982; 41: 405-8.

10 Meretey K, Falus A, Bohm V, Permin H, Wiik A. IgE class immune complexes in Felty's syndrome: characterisation of antibody activities in isolated complexes. Ann Rheum Dis antibody activities in

11 De Clerck L S, Westedt M L, Cats A, et al. IgE deposition in normal skin of patients with rheumatoid arthritis in relation to clinical and laboratory findings. Ann Rheum Dis 1985 4: $772-7$

12 Permin $\mathrm{H}$, Wiik $\mathrm{A}$. The prevalence of IgE antinuclear antibodies in rheumatoid arthritis and systemic lupus erythematosus. Acta Pathlogica et Microbiologica Scandinavica Sect C 1978; 86: 245-9.

13 Spiegelberg H L, Melewicz F M. Fc receptors specific for IgE on subpopulations of human lymphocytes and monocytes. Clin Immunol Immunopathol 1980; 15: 424-33. 